\title{
A literature review of economic studies on carbon pricing and Australian wholesale electricity markets
}

\begin{abstract}
With the ongoing development of Australian anthropogenic climate change mitigation policies, there has been a steady increase in modeling studies undertaken to estimate Australian carbon prices and their impact on existing electricity markets. This article summarises some of the more prominent studies completed by many of Australia's foremost economic modelling firms. We developed a simple approach for testing the consistency of these studies and their findings in relation to carbon pass-through. Unfortunately, we have established that the studies are entirely inconsistent in their estimation of carbon pass-through. Furthermore, we were unable to establish why the estimation of carbon pass-through varies so significantly. This has important implications for policy makers given much of the compensation to be paid to households and businesses under the Clean Energy Future package is predicated on simple assumptions of carbon pass-through. Based upon our analysis of these economic studies, our conclusion is that Australian policy makers are best guided by relying upon the numerous a posteriori estimations of pass-through in the European Union Emissions Trading Scheme (ETS) rather than Australian a priori studies.
\end{abstract}

Keywords: Carbon Tax; Emissions Trading; Electricity Prices

\section{Introduction}

The regulation of greenhouse gas emissions to address anthropogenic climate change has become a significant public policy issue throughout the world in recent years. In 2011, the Australian Government passed the Clean Energy Act 2011, resulting in a carbon price being applied to Australian industry from 1 July 2012. Previously, Australia had established the first (baseline and credit) emissions trading scheme in the world to reduce emissions in Australia ${ }^{1}$ and has had four significant government reviews into greenhouse gas emission regulation since 2004. All of these reviews produced detailed economic modelling of the potential impacts on the Australian economy and in particular the energy sector. In addition to the government commissioned modelling reports, there have also been a number of similar economic modelling reports completed for industry associations, individual companies and non-government organisations (NGOs). Unfortunately for policy makers, these studies have put forward wide-ranging and contradictory views of the impact on electricity and gas markets as a result of the introduction of greenhouse gas emissions trading. 
Australia's wholesale electricity prices are among the lowest in the world. Historically low energy prices have led to the development of large energy intensive industries such as aluminum smelting. Many of these industries are almost solely producing commodities for export and are therefore 'trade exposed' and sensitive to any increase in electricity prices. At the household level, the Australian Bureau of Agricultural and Resource Economics (ABARE 2010) has found that residential electricity prices are the fourth lowest of all OECD countries and Simshauser et al. (2010) established in 2008 that an average household electricity bill represented just $2.4 \%$ of average household income. Accordingly, any increase in electricity (and gas) prices is likely to be a relatively topical issue in Australia for both businesses and households as it is likely to be applied from a comparatively low base when assessed globally.

In this context, it is critical that policy makers understand how electricity and gas prices will be impacted with the introduction of an emissions trading scheme. Significant decisions have been made by the Australian Government in relation to compensation paid to industry and households under the Clean Energy Future Act which are based upon simple assumptions related to the impact of carbon pricing on electricity and gas prices. Accordingly, the purpose of this paper is to examine the consistency of economic modelling related to this important issue. This study provides a platform for further research by highlighting the inconsistency of research to date.

Australia's electricity consumption is predominantly fuelled by coal-fired electricity generation with a greenhouse gas emissions intensity significantly higher than many other countries. As a result, Australia's emissions per unit of GDP are around twice the level in comparable countries, $0.78 \mathrm{~kg}$ of carbon dioxide equivalent $\left(\mathrm{CO}_{2} \mathrm{e}\right)$ per unit of Gross Domestic Product (GDP) compared to only $0.43 \mathrm{~kg}$ of $\mathrm{CO}_{2} \mathrm{e}$ per unit of GDP in the OECD (IEA 2009). The Australian economy is therefore more exposed to the risks associated with placing a price on carbon (and the impact on domestic energy prices) than the average nation within the OECD.

\footnotetext{
${ }^{1}$ The New South Wales Greenhouse Gas Abatement Scheme (GGAS)
} 
While Australia's emissions are relatively high when assessed globally, it is also worth noting the context within which any energy prices are likely to be affected by carbon pricing. Simshauser et al. (2010) demonstrated that carbon pricing is likely to have a very small impact on electricity prices irrespective of assumptions related to carbon pass through. While the study concluded that by 2015, electricity prices in New South Wales and Queensland are likely to have increased by up to $116 \%$ relative to 2008 tariffs, $70 \%$ of this increase will be due to rising commodity prices and higher capital expenditure on distribution networks, and a further $22 \%$ would be non-carbon related cost pressures across the electricity supply chain. Therefore, it is important to keep the impacts of carbon pricing on energy markets in perspective. Unless prices increase beyond the $\$ 20-35$ per tonne $(\mathrm{t})$ of $\mathrm{CO}_{2} \mathrm{e}$ range forecast by most economic modelling firms, it is anticipated that carbon pricing will have a comparatively small impact on energy pricing all other things being equal.

Carbon pass-through in this paper is defined as the proportion of carbon prices (expressed in $\$ /$ tonne of $\mathrm{CO}_{2} \mathrm{e}$ ) passed through into electricity prices (expressed in $\$ / \mathrm{MWh}$ ). Carbon passthrough is effectively the proportion of higher costs incurred by consumers in the form of higher electricity prices attributable to a price on carbon - the key metric used by policy makers and a key input into general equilibrium modelling of the impacts on the broader macroeconomy of emissions trading.

This article is structured as follows: Section 2 outlines emissions trading policy developments and the economic modelling activity undertaken by government agencies and economic consultants at various points over the past few years; Section 3 provides an outline of the theoretical estimation of carbon pass-through and some of the key drivers; Section 4 presents a literature review of the various economic modelling studies done in recent years; a similar literature review for empirical studies on the existing European Union Emissions Trading Scheme (EU ETS) is provided in Section 5; and Section 6 outlines implications for policy makers and concluding remarks. 


\section{Australian Emissions Trading Economic Modelling Developments}

Australia has debated the merits of introducing an ETS with intermittent enthusiasm for around two decades now. It was 1992 when the Senate Standing Committee on Industry Science and Technology recommended that natural gas be more widely adopted for electricity generation in order to address greenhouse gas emissions. At around the same time economists at the Australian Bureau of Agricultural and Resource Economics (ABARE) began to consider similar issues. Hinchy (1993) published A Tradable Emission Permits Scheme which succinctly set out in the Australian context, the benefits of an ETS, including equalizing (and thus minimising for a given target) marginal abatement costs.

Against the backdrop of ongoing negotiations internationally through the United Nations Framework Convention on Climate Change (UNFCCC), the domestic policy response continued to be debated. During the same year that the UNFCCC negotiated the Kyoto Protocol, the Australian Inter-Governmental Committee on Ecological Sustainable Development released a discussion paper on directions for a National Greenhouse Gas Strategy. In its submission to the consultation on the Strategy, the Productivity Commission (then known as the Industry Commission) urged the Committee to further research the use of market mechanisms, including the use of tradable emission permits, to minimise the cost of emission reductions over the long run. The Productivity Commission's research noted that tradable permits between power generators could deliver a lower cost outcome than an externally determined tax rate on carbon emissions.

The ABARE continued actively to investigate the implications of UNFCCC negotiations, including the exploration of the benefits of an ETS as a policy response. As part of its review of energy market reform, the 2002 Parer Review considered in significant detail the form and nature of a national ETS. ACIL Tasman was commissioned to assist and with strong reliance on the 
Australian Greenhouse Office's work, the Review recommended an economy-wide ETS be adopted, as the least-cost mechanism to reduce greenhouse gas emissions (Council of Australian Governments (2002), p.233).

The years 2005 and 2006 saw significant developments in the quantification of the potential impacts of an ETS in Australia. Industry for the first time partnered with other stakeholders to progress the ETS policy debate, including the commissioning of important modelling exercises. This collaboration produced two important studies: Allens Consulting Group (2006) report to the Australian Business Roundtable on Climate Change and Options for Moving Towards a Low Emission Future.

The Australian Business Roundtable on Climate Change consisted of a diverse group of stakeholders across energy, insurance and conservation interests. The group commissioned macroeconomic modelling of emission trajectories to deliver a 60\% reduction in Australia's emissions by 2050 against 1990 levels. The modelling estimated the impacts to the economy of delaying action by 10 years to meet the 2050 target. Using GDP growth over the period to measure the impacts, the Allens Consulting Group concluded growth would be marginally lower to 2050 under the delayed action scenario, $1.9 \%$ compared to $2.1 \%$ under early action assumptions. This counter-intuitive conclusion was driven by assumptions related to significantly higher carbon prices in the second half of the modelling period in the delayed action scenario. These higher carbon prices reflected the need to reduce emissions more quickly at the tail end of the modelling period due to the delay in reducing emissions.

Also in 2005, WWF-Australia partnered with The Australian Gas Light Company and Frontier Economics to model an electricity sector specific ETS. Using a range of scenarios to deliver a 120mt emission target for the sector by 2030, the study Options for Moving Towards a Low Emission Future provided a comparative range of net present value calculations for the significant transition of the electricity generation sector. The results were an important 
contributor to the policy debate that followed, providing insight to the marginal abatement cost to deliver the emission reduction pathways and the corresponding investment pattern in low emission generation.

At the same time, the National Emissions Trading Taskforce (NETT) commissioned McLennan Magasanik Associates Pty Ltd (MMA), to model the impact of an ETS on Australia's Electricity Markets. The NETT was a state and territory-based initiative that put forward the first detailed proposal for a national, energy-sector ETS. This work was part of a broader costs and benefits assessment undertaken by a consortium including MMA, Insight Economics, the Centre of Policy Studies and the Allen Consulting Group.

During the period of 2005 through 2006, federal government initiated exercises in quantifying the costs of emission reductions were limited. However, the Prime Minister's Task Group on Emissions Trading (TGET) released its report recommending a national ETS in May 2007. While the release of this report marked the emergence of a bi-partisan support for a national ETS, the TGET's assessment and recommendations reflected much on earlier work done nationally on such a proposal, including the 2002 Parer Review. Having earlier refused to ratify the Kyoto Protocol, the Howard Government's subsequent adoption of ETS policy for commencement in 2012 differed only on timing to the Labor Opposition who took a 2010 timing to the 2007 federal election.

The Rudd Government elected at the end of 2007 quickly commenced working on the Carbon Pollution Reduction Scheme (CPRS), an ETS proposal to be developed in parallel and informed by, the Labor-initiated Garnaut Climate Change Review. Constructed through a green and white paper process, both the CPRS and the Garnaut Climate Change Review relied extensively on the Commonwealth Treasury (2008) modelling of the economics of climate change mitigation. Described as one of the "largest and most complex economic modelling projects ever undertaken in Australia" (Commonwealth Treasury (2008), p.IV) the Low Pollution Future (LPF), set a new 
benchmark for macroeconomic (multi region) modelling of an ETS policy for Australia. The LPF modelling results provided strong support for the concept that an economy-wide ETS, with full exposure to an international carbon market, would deliver emission reduction targets at leastcost to the Australian economy. Although differing on significant issues regarding the basis for commencement and permit allocation, the CPRS and Garnaut Climate Change Review were consistent in the overall approach to an ETS framework.

In 2009 CPRS legislation was introduced to Parliament, the first time a federal Australian parliament considered adopting an ETS as law. The results of the LPF, and in particular the additional wholesale electricity market modelling played a key role in the establishment of assistance to coal-fired generators in the form of Australian Emission Unit (AEU) allocations. Using the modelling outputs from the LPF of electricity demand and carbon prices, the Government engaged MMA, ACIL Tasman and ROAM Consulting to model the impacts on coalfired generation of an ETS. The results of the three independent studies revealed some consistencies with respect to which class of coal-fired generators are most impacted, but also revealed significant variability on asset value impacts. The most consistent observation was that all brown coal-fired generators suffered asset value loss by 2020, whilst black coal-fired generation varied.

Ultimately, the CPRS Legislation's AEU allocation for coal-fired generation was informed not only by economic modelling, but also by confidential financial modelling and assessment. This financial assessment (Department of Climate Change (2009)) resulted in a near doubling of assistance to brown coal-fired generation, in the interests of promoting the Australian investment environment and security of electricity supply. Despite a significant policy development process, the ambitious CPRS, having been rejected twice by the Australian Parliamentary Senate, was effectively abandoned in February 2010. 
In 2011 the Commonwealth Government passed the Clean Energy Future package of legislation. As a consequence of this legislation being adopted, an emissions trading scheme has been established in Australia to take effect from 1 July 2012. The scheme commences with a three year fixed price period with the price in 2012/13 being $\$ 23$ per tonne of carbon dioxide equivalent $\left(\mathrm{CO}_{2} \mathrm{e}\right)$. This price will be payable by any corporation operating a facility with annual aggregate emissions more than 25,000 tonnes of $\mathrm{CO}_{2} \mathrm{e}$. Much of the significant financial assistance that will be paid to households and businesses is based upon the framework of the abandoned CPRS. Accordingly, assumptions made in relation to carbon pass through are key variables in the assistance payable to industry and households. It is therefore important that a critical examination of the empirical literature on carbon pass-through be conducted at this time.

\section{Theoretical Estimation of Carbon Pass-through}

Carbon pass-through at any point in time is effectively a calculation of the incidence of the carbon tax (or tradable emissions permit). Significant pass-through is indicative of consumers bearing a large proportion of the incidence of the tax. Low levels of pass-through are indicative of producers bearing a higher proportion of the incidence of the tax. At any single point in time, the carbon pass-through in any market will largely be driven by any combination of the following factors:

- Emissions intensity of the existing capital stock. All other things being equal, the emissions intensity of existing gas producers and electricity generators will have a significant impact on the rate of carbon pass-through. If the existing capital stock is greenhouse intensive, carbon pass-through would be significant relative to a scenario where the existing capital stock is not emissions intensive.

- Demand elasticity. The elasticity of demand will have a significant impact on the rate of carbon pass-through. It has long been established in economic theory that the greater the 
inelasticity of demand, the greater the incidence of taxation being experienced by consumers, rather than producers.

- Economics of existing substitutes. If there are firms producing lower emissions substitute products and operating with excess capacity, then the rate of pass-through may be lowered as higher emitting products are substituted by lower emitting products. For example, a low emissions gas-fired generator currently operating at a low capacity factor could be run harder to displace existing coal fired generation.

- Availability of 'offsets' or 'international credits'. In many emissions trading schemes, there are provisions which allow 'offsets' (e.g. forestry) or 'international credits' (e.g. Certified Emission Reduction (CER) units) to be surrendered for compliance. Offsets and international offsets reduce the requirement for domestic substitution of emissions intensive production and consumption. Accordingly, the average carbon intensity of the domestic economy will be higher ceteris paribus with higher availabilities of 'offsets' or 'international credits'.

- Market competition. The structure of the existing market will have a significant impact on the incidence of any type of tax. A market characterised by perfect competition will have significant existing differences to a market characterised by oligopolistic or monopolistic structures.

The factors listed above are likely to be the primary drivers of the rate of carbon pass-through at any particular point in time. However, there are temporal impacts which must be considered. Carbon pass-through should not be considered a static ratio. It is a dynamic variable and should change significantly over time as emissions trading achieves its objective, the decarbonisation of economies. Ultimately, if an economy is able to completely decarbonise itself, individual firms will not be required to purchase any permits reflecting a zero carbon pass-through rate. However, 
this does not mean that energy prices would be lower than in the absence of a carbon price. It is simply a function of the effective prohibition of any emission producing asset being in operation.

In the case of electricity generation, the market for electricity is relatively inelastic in the shortterm and comparatively elastic in the long-term. As with any significant input commodity, firms are unlikely to change their consumption in the short-term as capital is physically fixed and cannot be easily relocated. However, in the long-term, a non-trivial proportion of electricity demand is likely to be more elastic. While a certain fixed amount of each residential load is likely to be inelastic over the long-term due to the 'essential service' nature of the commodity, export/import competing industrial loads are likely to be more elastic due to their ability to relocate operations in parts of the world with comparably lower post-carbon electricity prices.

Table 1: Emissions Factors for Electricity Production

\begin{tabular}{|c|c|c|}
\hline Australian State & Emissions Factor (t/MWh) & Generation Output (TWh) \\
\hline New South Wales & 0.90 & 73.4 \\
\hline Queensland & 0.89 & 59.3 \\
\hline Victoria & 1.23 & 56.1 \\
\hline South Australia & 0.72 & 14.3 \\
\hline Tasmania & 0.32 & 8.5 \\
\hline National Weighted Average & 0.94 & - \\
\hline
\end{tabular}

The average intensity of the National Electricity Market (NEM) in Australia is currently about 0.94 tonnes $\mathrm{CO}_{2} \mathrm{e}$ per MWh, which as Simshauser and Doan (2008) noted is substantially above the European average of 0.35 tonnes. Table 1 presents the emissions factor and generation output for each individual region of the National Electricity Market (NEM). The intensities largely reflect the predominant technologies of the individual regions. In New South Wales and Queensland, black coal-fired power stations produce most of the electricity and have emissions intensities between 0.8 and 1.0 tonnes $\mathrm{CO}_{2} \mathrm{e}$ per MWh. However, in Victoria, brown-coal fired 
power stations have an emissions intensity of between 1.25 and 1.55 tonnes $\mathrm{CO}_{2} \mathrm{e}$ per MWh. In contrast, in South Australia, there has been an increasing proportion of wind generation in recent years with a substantial lowering of its regional intensity down to 0.72 tonnes $\mathrm{CO}_{2} \mathrm{e}$ per $\mathrm{MWh}$. Based upon a current National Electricity Market (NEM) wide emissions factor of 0.94 tonnes $\mathrm{CO}_{2} \mathrm{e}$ per MWh, if the incidence of a carbon tax is fully incurred by the consumer, the rate of pass-through would be 0.94 . In other words, if a carbon tax of $\$ 10$ per tonne is introduced, wholesale electricity prices would increase by $\$ 9.40$ per MWh. Put differently, an average increase in Short-Run Marginal Cost (SRMC) of $\$ 9.40$ per MWh would be fully recovered by an increase in prices. Such a scenario would be characterised by: price inelastic electricity demand, a low standard deviation from the mean of emissions intensity for individual electricity generators (i.e. low fuel switching capabilities); and a time lag for the introduction of substitute technology (i.e. switching from old coal to new gas). Alternatively, if the incidence of a carbon tax is fully incurred by the producer, the rate of pass-through would be zero. For example, if a carbon tax of $\$ 10$ per tonne is introduced, wholesale electricity prices would not increase at all. Such a scenario would be characterised by: price elastic electricity demand, a high standard deviation from the mean of emissions intensity for individual electricity generators (i.e. high fuel switching capabilities); and immediate introduction of substitute technology (i.e. switching from old coal to new gas).

\section{Literature Review - Australian Research}

In recent years, there have been a number of quantitative studies completed by leading Australian economic modelling firms. Importantly, very few of these studies are peer-reviewed and published by independent researchers. Most have been completed by consultants and funded by government, industry or non-government stakeholders (NGOs). These studies have generally been focused on forecasting: carbon pricing; the impacts of carbon prices on electricity prices (carbon pass-through); and the broader economic impacts associated with the introduction of 
emissions trading. The studies use a range of economic techniques but can be broadly classified using the following taxonomy:

- $\quad$ Linear program optimisation modelling;

- $\quad$ Linear program modelling utilising game theory;

- $\quad$ Computable General Equilibrium modelling; and

- $\quad$ Dynamic partial equilibrium analysis

Most of these studies employ a simple approach for contrasting the impacts of a carbon policy such as an emissions trading scheme. Models of the electricity market or broader economy are established and run without a carbon policy in place. These same models are then rerun with a carbon policy (acting as a constraint) in place. For the purposes of determining the rate of "carbon pass-through', we have utilised the following equation:

$C P R_{t}=\frac{\left(P E_{C, t}-P E_{B A U, t}\right)}{C P_{t}} X \frac{100}{1}$

where: $\mathrm{CPR}=$ carbon pass-through rate

$\mathrm{PE}_{\mathrm{C}}=$ price of electricity with carbon price $(\$ A U S / \mathrm{MWh})$

$\mathrm{PE}_{\mathrm{BAU}}=$ price of electricity without a carbon price $(\$ A U S / M W h)$

$\mathrm{CP}=$ carbon price $\left(\$ \mathrm{AUS} /\right.$ tonne $\left.\mathrm{CO}_{2} \mathrm{e}\right)$

The results for the range of studies surveyed are presented in Table 2. It is clear from this analysis that there is a significant range of modeled outcomes. 
Table 2: Summary of Economic Studies and Rates of Carbon Pass-through (PTR)

\begin{tabular}{|c|c|c|c|c|}
\hline Year & Study & Methodology & CPR (Y1) & Commentary \\
\hline 2005 & $\begin{array}{l}\text { Australian } \\
\text { Business } \\
\text { Roundtable on } \\
\text { Climate Change }\end{array}$ & $\begin{array}{l}\text { Allen Consulting use the MMRF- } \\
\text { Green CGE model to determine } \\
\text { broad macroeconomic impacts } \\
\text { associated with immediate emission } \\
\text { reductions and delayed emission } \\
\text { reductions }\end{array}$ & $\begin{array}{l}\text { Carbon pass-through is not } \\
\text { estimated but report cites analysis } \\
\text { of the US energy } \\
\text { market which suggests around } 75 \\
\text { per cent of the economic costs } \\
\text { would be passed through to } \\
\text { consumers }\end{array}$ & $\begin{array}{l}\text { As a macroeconomic study, it } \\
\text { focused on broader indicators, rather } \\
\text { than specifically on electricity prices } \\
\text { and carbon pass-through }\end{array}$ \\
\hline 2005 & $\begin{array}{l}\text { WWF-AGL- } \\
\text { Frontier } \\
\text { Economics }\end{array}$ & $\begin{array}{l}\text { LP model of the National Electricity } \\
\text { Market (NEM) based on least cost } \\
\text { dispatch - named WHIRLYGIG }\end{array}$ & $90 \%$ & Electricity sector specific study \\
\hline 2006 & $\begin{array}{l}\text { MMA Report for } \\
\text { the National } \\
\text { Emissions Trading } \\
\text { Taskforce }\end{array}$ & $\begin{array}{l}\text { Multi-area probabilistic dispatch } \\
\text { algorithm - named STRATEGIST }\end{array}$ & $17 \%$ & $\begin{array}{c}\text { Electricity sector specific study } \\
\text { (although MMRF - a CGE model - } \\
\text { was also used and considered by the } \\
\text { Taskforce) }\end{array}$ \\
\hline 2008 & $\begin{array}{l}\text { ACIL Tasman } \\
\text { Modelling for } \\
\text { ESAA }\end{array}$ & $\begin{array}{l}\text { LP model called PowerMark } \\
\text { (electricity simulation model) } \\
\text { integrated with GasMark (gas } \\
\text { market simulation model) and } \\
\text { Tasman Global (General } \\
\text { Equilibrium model) }\end{array}$ & $41 \%$ & $\begin{array}{l}\text { Comprehensive modelling across } \\
\text { multiple markets }\end{array}$ \\
\hline 2008 & Garnaut Report & $\begin{array}{l}\text { Multi-area probabilistic dispatch } \\
\text { algorithm - named STRATEGIST }\end{array}$ & $128 \%$ & $\begin{array}{c}\text { Electricity sector specific study } \\
\text { (although CGE modelling was also } \\
\text { used and considered by the Garnuat } \\
\text { Review) }\end{array}$ \\
\hline
\end{tabular}




\begin{tabular}{|c|c|c|c|c|}
\hline Year & Study & Methodology & CPR (Y1) & Commentary \\
\hline 2008 & $\begin{array}{l}\text { ROAM Consulting } \\
\text { Submission to } \\
\text { CPRS Green Paper }\end{array}$ & LP model known as 2-4-C & $105 \%$ & Electricity sector specific modelling \\
\hline 2008 & $\begin{array}{l}\text { ACIL Tasman } \\
\text { Modelling for } \\
\text { Commonwealth } \\
\text { Treasury }\end{array}$ & $\begin{array}{l}\text { LP model called PowerMark } \\
\text { (electricity simulation model) }\end{array}$ & $60 \%$ & Electricity sector specific modelling \\
\hline 2008 & $\begin{array}{l}\text { ROAM Modelling } \\
\text { for Commonwealth } \\
\text { Treasury }\end{array}$ & LP model known as 2-4-C & $51 \%$ & Electricity sector specific modelling \\
\hline 2008 & $\begin{array}{l}\text { MMA Modelling } \\
\text { for Commonwealth } \\
\text { Treasury }\end{array}$ & $\begin{array}{l}\text { Multi-area probabilistic dispatch } \\
\text { algorithm - named STRATEGIST } \\
\text { used with demand and supply } \\
\text { convergence achieved through use } \\
\text { of MMRF (CGE) }\end{array}$ & $107 \%$ & $\begin{array}{c}\text { The second year has been adopted as } \\
\text { the first year appeared to be an } \\
\text { anomaly at } 38 \%\end{array}$ \\
\hline 2009 & $\begin{array}{l}\text { Wounded Bull } \\
\text { (Simshauser and } \\
\text { Doan) }\end{array}$ & $\begin{array}{l}\text { NEMESYS - dynamic half-hourly } \\
\text { equilibria determined using strategic } \\
\text { exit bidding assumptions and } \\
\text { scenarios }\end{array}$ & $\begin{array}{c}78 \% \text { (Stable bidding behavior) } \\
102 \%-393 \% \text { (Exit scenarios) }\end{array}$ & $\begin{array}{l}\text { First Australian study to examine } \\
\text { strategic exit bidding behavior and } \\
\text { the potential impacts on carbon pass- } \\
\text { through }\end{array}$ \\
\hline 2010 & $\begin{array}{l}\text { Frontier } \\
\text { Economics } \\
\text { (IPART Price } \\
\text { Review) }\end{array}$ & $\begin{array}{l}\text { LP electricity model based on least } \\
\text { cost dispatch - named } \\
\text { WHIRLYGIG; and similar model } \\
\text { incorporating game theory generator } \\
\text { bidding (SPARK) }\end{array}$ & $\begin{array}{l}\text { LRMC }-76-80 \% \\
\text { Market }-96-111 \%\end{array}$ & $\begin{array}{l}\text { Study contrasts the differences in } \\
\text { modeled outcomes between 'LRMC' } \\
\text { and 'market' approaches }\end{array}$ \\
\hline
\end{tabular}


Table 2 outlines the results of each of the studies examined in this literature review. We have found that the rate of 'carbon pass-through' (CPR) in the first year of the modeled introduction of an emissions trading scheme (emissions constraint) varies significantly across modelling studies. The lowest result of $17 \%$ was produced by MMA (2006) with the highest result of $393 \%$ being produced by Simshauser and Doan (2007) reflecting a strategic and disruptive generator exit scenario where the marginal generator withheld substantial amounts of plant capacity ahead of imminent financial distress. The mean of the studies surveyed is a pass-through rate of $93.45 \%$. Importantly, the inconsistency established in Table 2 is found to exist beyond the first year of modelling results. This is shown in Figure 1 where carbon pass-through is plotted against time for those studies which examined a similar modelling timeframe.

Figure 1: Estimated modeled carbon pass-through in each year

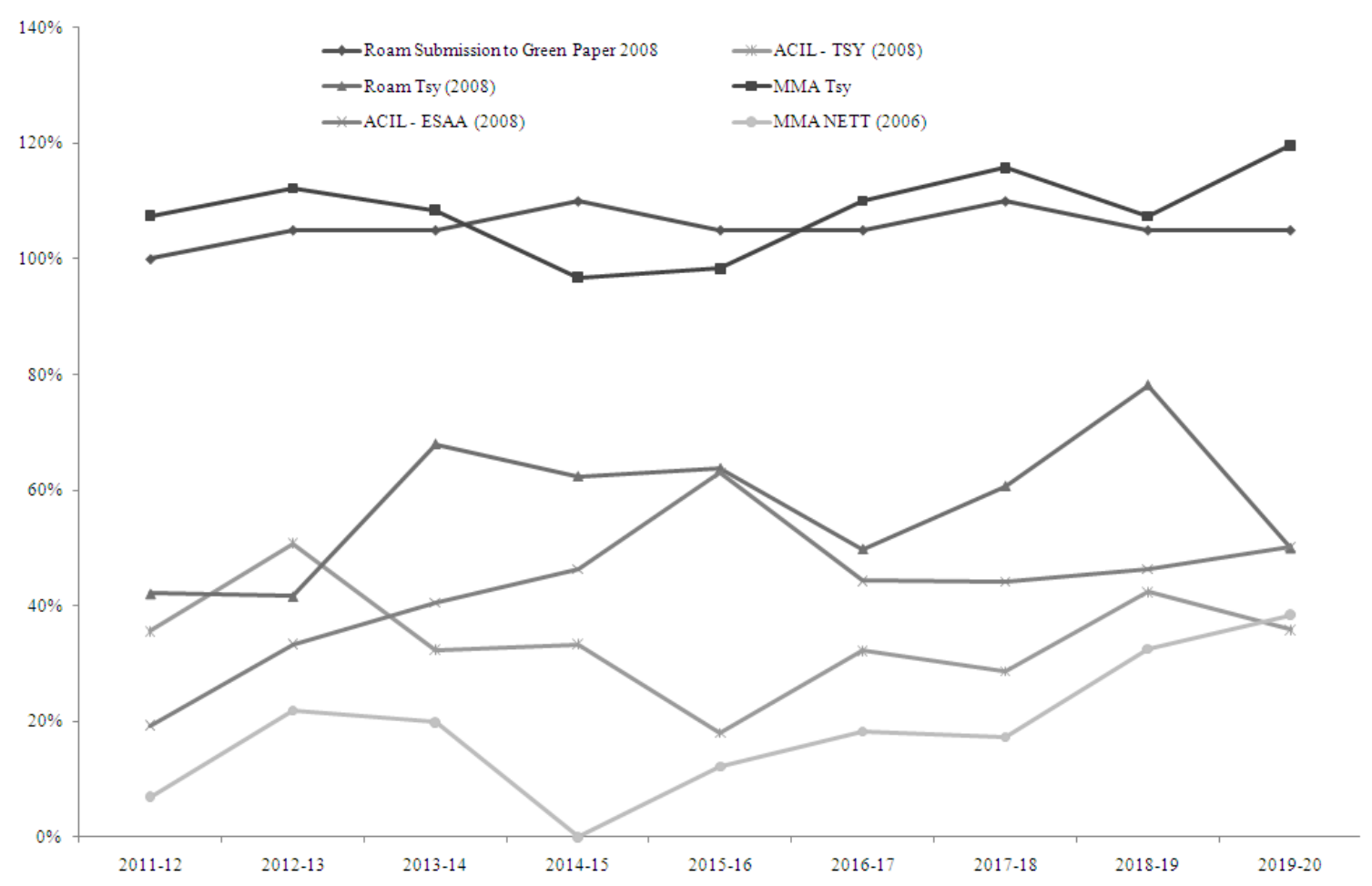

Based upon this detailed literature review, many of the variables that influence CPR discussed in the previous section are unlikely to play a role in the inconsistency of these results: 
- $\quad$ Emissions intensity of the existing capital stock. As emissions intensities of existing power stations are well known (within a very small degree of error), all of the studies use almost identical assumptions in relation to the existing capital stock.

- Demand elasticity. In the short-term, each study utilises similar assumptions in relation to demand elasticity. Most of the studies use independent forecasts by the Australian Energy Market Operator published in the Statement of Opportunities (For further information, see http://www.aemo.com.au/planning/esoo2011.html).

- Economics of existing substitutes. The fixed and variable costs of existing substitutes are similar in each of the studies. In most of the studies, assumptions are sourced from similar publications such as the fuel resource, new entry and generation costs in the National Electricity Market (NEM) publication by ACIL Tasman for the Australian Energy Market Operator (For further information, see http://www.aemo.com.au/planning/419-0035.pdf for an example of this type of publication).

The influence of generator bidding behavior on CPR is a key assumption that goes some way to explaining the variation in results. However, it only explains the variation in results between studies that utilise a least cost (long-run marginal cost) model and those studies that incorporate bidding behavior. Frontier Economics (2010, p.80) provide a clear explanation of why the rates of pass-through may vary across studies that use LRMC as opposed to a market based approach: ...carbon pass-through in the market-based approach is much higher than in the LRMC case. This reflects the fact that in reality (which is better reflected in market based approach) investment cannot respond to the carbon price within the period of the current determination; only the dispatch of existing plant can change to meet the target within this short timeframe. Given that the existing stock of plant has a higher average emissions factor than any hypothetical new system of plant, the level of 
carbon pass-through is higher in the market-based approach......High levels of carbon pass-through at the beginning of a cap and trade scheme are an indication that the scheme is working and that new, low emission investment will occur in the future, eventually lowering the average emissions of the NEM and the carbon passthrough...

While this explanation goes to why market based studies come to different conclusions to those that use a simple LRMC approach, it cannot explain the wide variety of results in our literature review. Many of the studies use very similar methodologies and have significantly different conclusions. Where sensitivities were modeled within each specific study, there was little observed impact on rates of CPR. Based upon the evidence provided, we are unable to explain why such significant variations in results exist. We can only conclude that unfortunately this evidence alone would provide policy makers with no real guidance on the likely rate of carbon pass-through as a result of the introduction of an emissions trading scheme.

\section{Literature Review - EU ETS}

The literature review presented in Section 4 is an examination of a priori research on the potential impacts of the introduction of an emissions trading scheme in Australian electricity markets. Until an emissions trading scheme is actually introduced in Australia, it is impossible to state conclusively what the impacts will be on electricity and gas markets with complete certainty. However, there are other cap and trade greenhouse gas emissions trading schemes operating in the world that may provide guidance on the potential impacts. In fact, there are numerous $a$ posteriori studies that have been undertaken on other schemes which are reviewed in this Section.

The largest emissions trading scheme in the world is the European Union Emissions Trading Scheme (EU ETS). There have been numerous studies completed that attempt to summarise the pass-through of EUA (Emission Unit Allowances) into wholesale electricity prices under the operating scheme. Some of the more prominent studies are summarized below: 
- $\quad$ Bauer and Zink (2005) found that the rate of pass-through in Germany was 0.52. This rate almost perfectly correlates with the average intensity of the German market at the time (0.53 tonnes per MWh).

- Bunn and Fezzi (2007) determined that the rate of pass-through in the UK spot market for electricity between April 2005 to May 2006 was 0.42. The average emissions intensity of the UK market is around 0.48 tonnes per MWh.

- Chernyavs'ka and Gulli (2007) determined that the rate of pass-through during each trading period (marginal pass-through) reflected the generation being operated at the time in Italian power market.

- Fell (2008) analysed Nordic wholesale electricity prices and their response to changes in EUA prices using a cointegrated vector autoregressive model. The study found near complete pass-through of EUA prices.

- $\quad$ Frontier Economics (2006) undertook regression analysis on a number of variables to determine that the correlation between EUA prices and wholesale electricity prices (both peak and off-peak) was between 0.89 and 0.97 in the UK and the Netherlands.

- $\quad$ Perrels et al (2006) found that between $75 \%$ and $95 \%$ of the price change in the EUA market was passed through to Finnish Nord Pool spot market. Importantly, the authors also examine the impacts of demand variability and find that the rate of pass-through at times of low electricity demand is half that experienced at times of high demand.

- $\quad$ Sijm (2006a and 2006b) analysed wholesale electricity markets in Germany and the Netherlands and found that the 'pass-through rate' was between 0.60 and 1.17 .

These studies are only a handful of the numerous studies completed by economists throughout the EU. For example, Sijm (2008) provides a comprehensive review of the studies completed on the EU ETS which we do not intend to reproduce here. Based upon our review of these studies, it 
would superficially appear that the rate of pass-through is very much dependent upon the average emissions intensity of the market. One of the most authoritative publications on carbon passthrough rates is contained within a report by Reinaud $(2007$, p.5) where it states that:

.. if any evidence is needed of the CO2 pass-through into electricity prices, it was provided by the abrupt fall of the CO2 price in May 2006, as market players were made aware of the excess quantity of EU allowances for the year 2005. The fall by $€ 10 / t C O 2$ was immediately followed by a drop in 5 wholesale electricity prices of $€ 5-10 / M W h$. This electricity price adjustment can be directly attributable to the CO2 price fall, itself not connected to other energy market movements that could also affect electricity prices...

\section{Policy Implications}

The objective of placing a price on carbon pollution is to inform the market of an input cost that will alter the competitive landscape and drive a substitution of higher-emitting activities by lower-emitting activities. In the confines of the Australian wholesale electricity market this substitution translates to the shift from coal-fired generation to gas-fired and renewable electricity generation sources. Given the objective of substitution, the impact of a carbon price on wholesale electricity prices and in particular the degree of pass-through has significant implications for policy-makers.

Where pass-through rates are high, retail prices are likely to reflect the full or near full cost of carbon. Electricity is both an essential service and a key input to most economic activity, and it is this context that price changes must be evaluated. The effect of this price signal can drive behaviour change and substitution for consumers, such as energy efficiency measures or changes to energy sources. A price signal also incentivises customers and companies to invest in innovative new products and services such as in-home displays and remote load management. Such outcomes are desirable and will assist in achieving abatement outcomes for the electricity sector. 
Unfortunately, carbon pass-through can also drive undesirable outcomes such as the relocation of energy intensive industry to alternative, greenhouse gas emitting countries, an outcome commonly referred to as "leakage". For policy-makers, carbon pass-through rates will inform decisions around complimentary measures to assist industrial consumers, be it through direct assistance to manage the costs of price rises, introduction of energy efficiency measures, or targeted programs to avoid leakage.

In this context, the Australian Government has introduced substantial assistance for households and businesses with the Clean Energy Future package of legislation (see Commonwealth Government, 2011). The introduction of a carbon price on 1 July 2012 is accompanied by significant changes to personal income taxation rates and the provision of free emission permits to large energy intensive industry and electricity generators. Crucially, the government has utilised a high rate of pass-through in its modelling of the impacts of carbon pricing on electricity bills for businesses and households. This is demonstrated by the calculation that the Consumer Price Index is forecast to be impacted by $0.7 \%$ with the introduction of a carbon price of $\$ 23 / \mathrm{t}$ on 1 July $2012^{2}$, implying that almost all of the $\$ 8$ billion paid for carbon permits will be passed through in the form of higher consumer prices. From a public policy perspective, it is necessary to consider the assumptions made around high rate of pass-through against the inconclusive evidence presented in this paper. If the rate of pass-through is lower or higher than the rate assumed by the Commonwealth Government, assistance provided will be either excessive or inadequate respectively.

In addition, significant decisions by government will need to be taken in relation to retail pricing (electricity pricing for households is regulated by government in Queensland, New South Wales, Tasmania and South Australia). Given the importance of carbon pass-through as a key determinant in understanding the economics of retail electricity and gas tariffs, we believe it is

\footnotetext{
${ }^{2}$ Contrasted against a national GDP of around \$1.3 trillion, raising \$8 billion in permit revenue (see Commonwealth Government, 2011, p. 131) implies that prices will increase by $0.62 \%$ assuming full carbon pass through. This is very close to the official Treasury estimate of $0.7 \%$, implying high rates of carbon pass-through.
} 
critical that policy makers develop a greater understanding of carbon pass through in the Australian context.

\section{Concluding Remarks}

This article has attempted to provide some guidance for policy makers in navigating their way through the numerous and conflicting studies done to date on the impacts of carbon pricing on wholesale electricity markets. We have been unable to determine why the studies vary significantly but have noted that the average rate of pass through calculated by the studies in our sample is $93.45 \%$. This is not dissimilar to the current average emissions intensity of the National Electricity Market which is 0.94 tonnes per MWh and is reasonably consistent with experiences in Europe. However, given the significant variation in results, we recommend that further research by completed to analyse why the findings of the studies we included in our literature review varied so considerably. ${ }^{3}$

Even so, price increases related to carbon need to be put into perspective. A recent study by Nelson et al. (2010) demonstrated that the costs of uncertainty in relation to inaction on climate change policy is likely to result in electricity prices increasing by around $\$ 8.60$ per MWh more than necessary due to the introduction of a sub-optimal capital stock. Furthermore, Simshauser et al. (2010) has forecast that electricity prices are likely to increase by around $\$ 140$ per MWh due to higher network capital expenditure and commodity price increases. In this context, the rate of pass-through, while important, is likely to be a minor contributor to retail price increases. However, it will be an important variable in the determination of many policy settings including any financial assistance to energy intensive trade exposed industry.

\footnotetext{
${ }^{3}$ A reviewer of this manuscript has made an important observation which the authors agree with. It should be noted that the average rate of pass through, or CPR is a dimensionless measure, while the emissions intensity has units of tonnes per MWh. While ceteris paribus, the CPR in a jurisdiction can be expected to be roughly proportional to the emissions intensity of electricity generation in that jurisdiction the numerical similarity of the two measures is coincidental.
} 


\section{References}

ACIL Tasman (2008), The impact of an ETS on the energy supply industry, ACIL Tasman Publications, Melbourne

ACIL Tasman (2008), Impacts of the Carbon Pollution Reduction Scheme and RET - Modelling of impacts on generator profitability, ACIL Tasman Publications, Melbourne

ACIL Tasman (2009), Fuel resource, new entry and generation costs in the NEM, ACIL Tasman Publications, Melbourne

Allens Consulting Group, (2006), Deep Cuts in Greenhouse Gas Emissions - Economic, Social and Environmental Impacts for Australia, March 2006 Report to the Business Roundtable on Climate Change

Australian Bureau of Agricultural and Resource Economics (ABARE) (2010), Energy in Australia 2010, Commonwealth Government Publication, Canberra

Bauer, C., and J. Zink (2005): Korrelation zwischen Strompreisen und CO2-Zertifikatepreisen, Energiewirtschaftliche Tagesfragen, Vol. 55, No. 8, pp. 574-577

Bunn, D., and C. Fezzi (2007): Interaction of European Carbon Trading and Energy Prices, London Business School, London

Bunn, D., and C. Fezzi (2008): "A vector error correction model of the interactions among gas, electricity and carbon prices: an application of the cases of Germany and the United Kingdom”, in: Gulli, F., ed., Markets for Carbon and Power Pricing in Europe - Theoretical Issues and Empirical Analyses, New Horizons in Environmental Economics, Edward Elgar, Cheltenham, UK, and Northampton, MA, USA, pp. 145-159

Chernyavs'ka, L., and F. Gulli (2007): "Marginal CO2 pass-through under imperfect competition in power markets, Ecological Economics, Vol. 68, No. 1-2, pp. 408-421

Commonwealth Government (2011), Securing a clean energy future: The Australian Government's climate change plan, Commonwealth Government Publication, Canberra

Commonwealth Government White Paper (2008), Carbon Pollution Reduction SchemeAustralia's Low Pollution Future. Commonwealth Government, Canberra

Commonwealth Treasury (2008), Australia's Low Pollution Future - The Economics of Climate Change Mitigation, Commonwealth Government, Canberra

Council of Australian Governments Energy Market Review (2002), Towards a truly national and efficient energy market, Council of Australian Governments, Canberra

Department of Climate Change (2009), Proposed Package of Measures to Safeguard the Security of Australia's Electricity Supplies. Commonwealth Government, Canberra

Fell., H, (2008), "EU-ETS and Nordic Electricity - A CVAR Analysis", Discussion Paper Resources of the Future, Washington 
Frank, R. (2009), The Return of the Economic Naturalist, Virgin Books, London

Frontier Economics (2006): The Role of CO2 in power markets - in line with Competition, Paper by Riechmann, C., M. Etten, and N. Elms, London

Frontier Economics (2010), Energy purchase costs, A final report prepared for IPART, Frontier Economics Publication, Melbourne

Garnaut Climate Change Review, (2008), Final Report of the Garnaut Climate Change Review, Commonwealth Government, Canberra

Hinchy, M., Thorpe, S. and Fisher, B.S. A Tradable Emission Permits Scheme, ABARE Research Report 93.5, Canberra, 1993

Honkatukia, J., V. Mälkönen, and A. Perrels (2008): "Impacts of the European Emissions Trading Scheme on Finnish wholesale electricity prices", in: Gulli, F., ed., Markets for Carbon and Power Pricing in Europe - Theoretical Issues and Empirical Analyses, New Horizons in Environmental Economics, Edward Elgar, Cheltenham, UK, and Northampton, MA, USA, pp. 160-193

International Energy Agency (2009), Key World Energy Statistics 2009, International Energy Agency Publication, Paris

McLennan Magasanik Associates (2006), Impacts of a National Emissions Trading Scheme on Australia's Electricity Markets, MMA Publication, Sydney

McLennan Magasanik Associates (2008), Impacts of the Carbon Pollution Reduction Scheme on Australia's Electricity Markets, MMA Publication, Sydney

National Emissions Trading Taskforce (2006), Possible Design for a National Greenhouse Gas Emissions Trading Scheme, New South Wales Government, Sydney

Nelson, T., Kelley, S., Orton. F and Simshauser, P., (2010), "Delayed carbon policy certainty and electricity prices in Australia", Economic Papers, Vol. 29, No. 4, pp. 1-20

Prime Minister's Task Group on Emissions Trading (2007), Report of the Task Group on Emissions Trading, Commonwealth Government, Canberra

Reinaud, J., (2007), “Impact on industry's electricity purchasing strategies in Europe”, IEA Information Paper, International Energy Agency, Paris

ROAM Consulting (2008), Submission to the Commonwealth Government CPRS Green Paper, ROAM Consulting Publication, Brisbane

ROAM Consulting (2008), Modelling of carbon pricing scenarios, ROAM Consulting Publication, Brisbane

Sijm, J., Hers, S., Lise., W and Wetzelaer. B, (2008), "The impact of the EU ETS on electricity prices", Energy Research Centre of The Netherlands, Amsterdam 
Sijm, J. (2006a): Implications of CO2 Cost Pass-through in the Power Sector, Presentation at the Ad hoc High Level Group meeting on EU ETS, DG Environment, Brussels, March 30, 2006

Sijm, J., K. Neuhoff and Y. Chen (2006b): "CO2 Cost Pass-through and Windfall Profits in the Power Sector”, Climate Policy, Vol. 6, No. 1, pp. 49-72

Simshauser, P. (2008), "On Emission Permit Auction vs. Allocation and the Structural Adjustment of Incumbent Power Generators in Australia", The Electricity Journal, Vol. 21, Issue 10, pp.30-41

Simshauser, P. and Doan, T (2009), "Emissions Trading, Wealth Transfers and the Wounded Bull Scenario in Power Generation", The Australian Economic Review, Vol. 42, No. 1, pp.64-83

Simshauser, P., Nelson, T. and Doan, T. (2011), “The Boomerang Paradox Part I: how a nation's wealth creates fuel poverty - and how to defuse the cycle", Electricity Journal, In-press

WWF-Australia, Frontier Economics and AGL, (2006), Options for moving towards a low emission future, The Australian Gas Light Company, Sydney. 